\title{
Mental Health Problems in Nepalese Migrant Workers and their Families
}

\author{
- Pashupati Mahat ${ }^{1,2} \bullet K^{2}$ an Thorley ${ }^{3}$ Karuna Kunwar ${ }^{1,4} \bullet$ Smriti Ghimire ${ }^{1}$
}

Submitted 25 September 2020

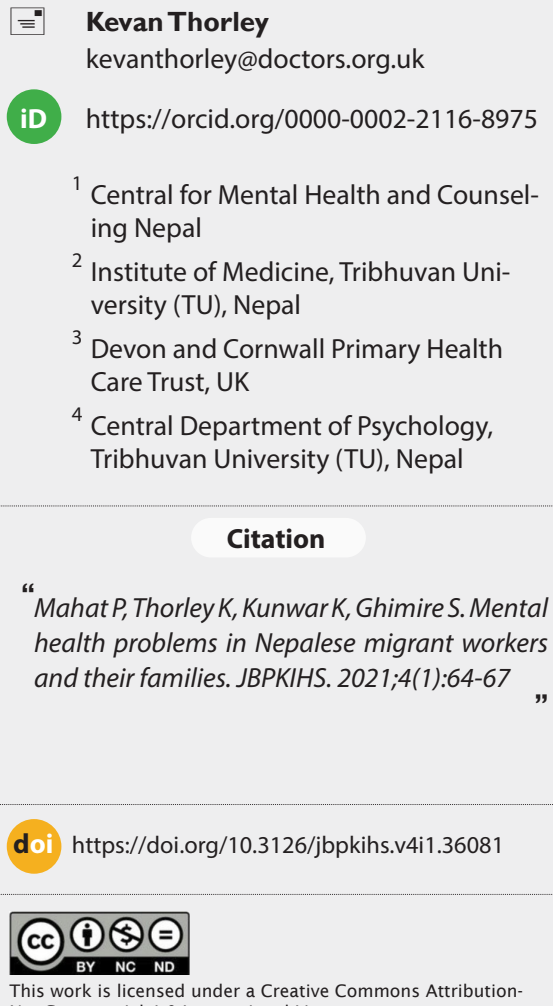

2 Institute of Medicine, Tribhuvan University (TU), Nepal

${ }^{3}$ Devon and Cornwall Primary Health Care Trust, UK

${ }^{4}$ Central Department of Psychology, Tribhuvan University (TU), Nepal

Citation

"MahatP, ThorleyK, KunwarK, GhimireS. Mental health problems in Nepalese migrant workers and their families. JBPKIHS. 2021;4(1):64-67

doi https://doi.org/10.3126/jbpkihs.v4i1.36081

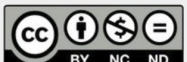

This work is licensed under a Creative Commons AttributionNonCommercial 4.0 International License.
Accepted 23 February 2021

Published 30 June 2021

In this cross-sectional study, we aimed to assess the mental health problems of Nepalese migrant workers and their family members at home in Nepal. Families of migrant workers left behind in Nepal from nine project districts were interviewed to assess the psychosocial problems and offered appropriate psychosocial counseling. We assessed 747 individual members. Ninety-five returned migrant workers received psychosocial counseling, $67 \%$ of whom were males. The majority (56\%) of returnees suffered from anxiety, $23 \%$ had depression and $11 \%$ had serious mental illness. The left-behind family members amounted to $652,93 \%$ of whom were females. The majority (56\%) had anxiety, $25 \%$ had depression, $7 \%$ expressed suicidal ideation or had attempted suicide, and $2 \%$ had severe mental illness. We concluded that the majority of returning workers and left behind family members suffered from anxiety and depression.

Keywords: Anxiety, Depression, Mental health, Migrant workers, Psychosocial support

\section{Declarations}

Ethics approval and consent to participate: Ethical approval for this study granted by the Ethical Review Board of the Nepal Health Research Council (Ref No. 1209). Informed con-sent was taken from the participants.

Consent for publication: Not applicable

Availability of data and materials: The datasets used and/or analyzed during the current study are available from the corresponding author on reasonable request. All relevant data are within the manuscript.

Competing interest: None

Funding: No specific funding received for research. Counseling services was supported by SaMi/ HELVETAS.

Authors' contributions: PM: concept, data collation and analysis. KT: data analysis, manu-script preparation. KK: design, data collection, data analysis. SG: design, data collection, data analysis. All the authors have read and approved the final manuscript.

Acknowledgement: None 
$\mathrm{N}$ epal has an economy increasingly dependent on remittances from migrant workers [1]. The separation of families causes social and psychological problems. The left behind members, especially the women and children experience social isolation, abuse, harassment, breakdown of relationships among family members and community, and social stigma [2]. In Sri Lanka, two in every five left-behind children were shown to have mental disorders and over a quarter of the left-behind children were underweight or severely underweight [3].

The Safer Migration Project is a bilateral initiative of the Government of Nepal and the Government of Switzerland [4]. The project is implemented through a partnership between HELVETAS Swiss Intercooperation Nepal and the Ministry of Labour, Employment and Social Security. The Centre for Mental Health and Counseling Nepal, a national partner of the Safer Migration Project, has been supporting the program by providing psychosocial support to the families of migrant workers and distressed returnee migrants in nine project districts ranging from the hill regions to the plains of the Terai since 2013. We aimed to describe the psychosocial issues experienced by returned migrant workers and the families of returned and absent migrant workers covered by the project.

\section{METHODS}

$\mathrm{E}$ thical approval for this study was granted by the Ethical Review Board of the Nepal Health Research Council. The project was implemented in Khotang, Sarlahi, Ramechhap, Nawalparasi, Dhanusha, Kailali, Dhading, Nuwakot and Sindhupalchowk districts between July 2015 and June 2016.

The psychosocial intervention component of the project included building the capacity of staff. Four staffs from each district were trained in psychosocial counseling during six months practice-based training program. Thirty-nine counselors received a training course of 900 hours: 440 hours theory and 460 hours supervised practice. Trainee counselors maintained the case documentation including details of counseling session plans before the sessions with the help of the assigned psychologist supervisor. Five clinical psychologists were involved in supervision.

Selection criteria for the sample population included returned migrant workers with psychosocial and mental health conditions and the families of migrant workers working in six Gulf countries and Ma- laysia. We included all the family members of migrant workers. The sample (beneficiaries of the project) were identified through the help of local returnee volunteers, school teachers, local media, the information and counseling center, women's network groups, and the district police office.

The project attempted to address psychosocial problems through a service delivered by trained counselors who visited affected families, developed trust with individual clients and family members and explored the problems. The aim of the intervention was to reduce symptoms by strengthening the ability of clients to cope with their situations and feelings. The psychosocial skills adopted were active listening, helping to analyze the consequence of the suffering of a client, helping to change the focus of the client from symptoms and relationship problems to functional abilities and strengths, tips for self-care such as dietary advice, sleep hygiene, and stress-reducing breathing exercises and intervention focused questions.

Data were collected by the counselors working with returnee workers and their families and entered into an excel spreadsheet. The diagnosis was assigned by the psychologists on the basis of the case records discussed with the counselors during supervision.

\section{RESULTS}

The project supported 747 individual clients with a psychosocial counseling service through 36 counselors in the one-year period. This included a total of 95 returnee migrant workers and 652 left behind family members. The majority of left behind family members were females (93\%). Majority of them were wives (68\%) or mothers (19\%) of the migrant workers. Six percent of the clients were children while the maximum number of clients (38\%) were of age 26-35 y (Figure 1).

Psychosocial problems encountered by the returnee migrant workers and the left behind family members were grouped as anxiety, depression, suicide attempt/ risk and severe form of mental illness (Table 1). The contributing factors reported included work-related problems such as low pay, illegal status and violence.

\section{DISCUSSION}

$\mathbf{W}^{\mathrm{e} \text { found the prevalence of depression and anxiety in }}$ the families of migrant workers to be $25 \%$ and $58 \%$ respectively, which was twice than that found in the general population of Nepal [5]. Returnee migrant workers 
Table 1: Psychosocial problems experienced by returnee migrant workers and the left behind family members attending the psychosocial support program

\begin{tabular}{lllll}
\hline \multirow{2}{*}{ Psychosocial problems } & \multicolumn{2}{c}{ Returnee migrant workers } & \multicolumn{2}{c}{ Left behind family members } \\
\cline { 2 - 5 } & Male/ Female & Total $(\%)$ & Male/ Female & Total (\%) \\
\hline Anxiety symptoms & $46 / 7$ & $53(56)$ & $7 / 369$ & $376(58)$ \\
Depression & $8 / 14$ & $22(23)$ & $19 / 147$ & $166(25)$ \\
Severe form of mental illness & $6 / 4$ & $10(11)$ & $2 / 9$ & $11(2)$ \\
Suicide attempt/ risk & $2 / 4$ & $6(6)$ & $3 / 41$ & $44(7)$ \\
Others & $2 / 2$ & $4(4)$ & $16 / 39$ & $55(8)$ \\
Total & $64 / 31$ & $95(100)$ & $47 / 605$ & $652(100)$ \\
\hline
\end{tabular}

Figure 1: Age distribution (in years) of clients attending psychosocial counseling $(n=747)$ also reported higher levels of depression and anxiety than in the general population of Nepal.

Two studies on depression among migrant workers in Qatar and Saudi Arabia found a high prevalence of mental health problems [6, 7]. A telephone screening survey of 2520 migrant workers in Qatar found just over half screened positive for depression. A large number (26\%) of those surveyed were Nepali workers. The prevalence of a positive screen for depression was higher in labor migrants than in white collar workers [6]. A cross-sectional survey of 400 male migrant workers in Saudi Arabia found the prevalence of depression as $20 \%$; it did not vary by duration of stay or living condition but by age, stress, and self-reported health [7].

Women in Nepal experienced higher rates of depression than men [5]. Studies in Sri Lanka where nearly ten percent of the adult population is employed abroad as migrant workers, demonstrate a prevalence of mental disorder of $21 \%$ among spouses of migrant workers left behind and of 30\% in non-spouse caregivers [8]. Our findings of the prevalence of mental health problems in the families of left behind migrants are

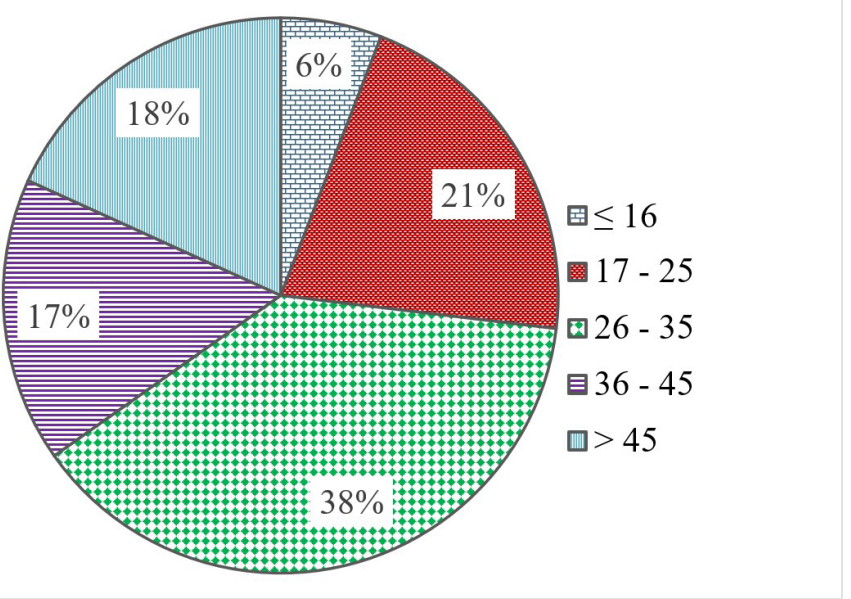

consistent with those of studies of left-behind families in other countries such as Sri Lanka and Jamaica $[8,9]$.

Limitations of this study include a small number of returning workers, especially those of women. We were not able to estimate severity by use of a standardized rating scale for depression and anxiety. Problems of data collection did not allow us to disaggregate some of the data relating to returnee workers and left-behind clients so that analysis of contributory factors between these two groups is unsatisfactory.

Future research may investigate further the work-related aspects of the mental health problems of returnee migrant workers and possible preventive strategies for workers and their left-behind family members.

\section{CONCLUSION}

$W_{58 \% \text { of left behind family members in Nepal suf- }}^{\text {e found that } 56 \% \text { of returnee migrant workers and }}$ fered from anxiety. In addition, $23 \%$ of returnee workers and $25 \%$ of left behind family members suffered from depression. 


\section{References}

I. Baruah N,Arjal N. The Asia Foundation [Internet]. Nepalese Labor Migration-A Status Report. 2018 Jun 6 - [cited 2019 Apr I6]. Available from: https://asiafoundation.org/2018/06/06/nepalese-labor-migration-a-status-report/.

2. Centre for Mental Health and Counselling Nepal.Annual report. 2015. p. 18-20.

3. Wickramage K, Siriwardhana C,Vidanapathirana P,Weerawarna S, Jayasekara B, Pannala G, et al. Risk of mental health and nutritional problems for left-behind children of interna-tional labor migrants. BMC Psychiatry.2015; I5:39. DOI: I0.1 I86/s I2888-0I5-04I2-2

4. SaMi: Safer Migration Project [Internet]. Lalitpur (Nepal): [publisher unknown]. [cited 202I May 2I].Available from: http://www. sami.org.np/

5. Risal A, Manandhar K, Linde M, Steiner TJ, Holen A. Anxiety and depression in Nepal: prevalence, comorbidity and association. BMC Psychiatry. 2016;16:102. DOI: I0.1 I86/s I2888-016-08I0-0

6. Khaled S, Gray R. Depression in migrant workers and nationals of Qatar:An exploratory cross-cultural study. Int J Soc Psychiatry. 2019;65(5):354-67. DOI: I0.1 177/0020764019850589.
7. Nadim W, AlOtaibi A, Al-Mohaimeed A, Ewid M, Sarhandi M, Saquib J, et al. Depres-sion among migrant workers in Al-Qassim, Saudi Arabia.J Affect Disord. 2016;206:103-8. DOI: 10.1016/j. jad.2016.07.037.

8. Siriwardhana C, Wickramage K, Siribaddana S, Vidanapathirana P, Jayasekara B, We-erawarna $S$, et al. Common mental disorders among adult memebrs of 'left behind' inter-national migrant worker families in Sri Lanka. BMC Public Health. 2015;15:200. DOI: I0.II86/s I2889-0I5

9. Jones A, Sharpe J, Sogren M. Children's experiences of separation from parents as a con-sequence of migration. Caribbean Journal of Social Work. 2004;3(I):89-109. 